\title{
Consumer Preference for Sea Fish Consumption in Dhaka City of Bangladesh
}

\author{
Md Enamul Haque ${ }^{1}$, Shahnaz Khanom ${ }^{1}$, Md Safiul Islam Afrad ${ }^{1}$, Aliyu Akilu Barau ${ }^{1,2} *$ and \\ S M Rafiquzzaman ${ }^{3}$
}

${ }^{I}$ Department of Agricultural Extension and Rural Development, Bangabandhu Sheikh Mujibur Rahman Agricultural University, Gazipur-1706, Bangladesh; ${ }^{2}$ Department of Agricultural Extension and Rural Development, Usmanu Danfodiyo University, Sokoto, Nigeria; ${ }^{3}$ Department of Fisheries Biology and Aquatic Environment, Bangabandhu Sheikh Mujibur Rahman Agricultural University, Gazipur-1706, Bangladesh

*Corresponding author and Email: akilutsafe@yahoo.com

Received: 07 April 2019

Accepted: 09 November 2019

\begin{abstract}
Fish is traditionally complemented to rice in the diet of Bangladeshi. Thus, its daily consumption is pretty normal. Although, a number of researches have been done on river fish and its consumption, there seems a few in the public that specifically studied consumer preference for sea fish consumption in Bangladesh. This study, therefore, explores the consumers' preference for sea fish consumption in Dhaka city of Bangladesh. A cross sectional survey design was followed to collect data from 120 respondents in four quota sampled areas of the city, namely; Uttara, Khilkhet, Mirpur and Jatrabari. The results revealed that 20 species of sea fish were usually brought to the markets patronised in the selected areas, but 17 were commonly consumed. The consumers mostly preferred Tenualosa ilisha (95.83\%), Pampus chinensis (91.67\%), Penaeus monodon (75.0\%), Lates calcarifer (74.17\%), Euthynnus affinis (62.5\%) and Harpadon nehereus (58.33\%) for their taste whereas, Pama pama (33.33\%) and Setipinna taty (46.67\%) were preferred for lower price. The average monthly household sea fish consumption was $5.49 \mathrm{~kg}$. Age, level of education, gender, annual income and religious view were found to have significant positive association with household sea fish consumption. Respondents preferred sea fish for health benefits related to heart, eye-sight, nutrient enrichment, diseases protection and prevention of depression. However, irregular supply of sea fish and higher price were pointed by the respondents as the main constraining factors to sea fish consumption. Generally, Bangladesh is blessed with vast sea fish resources, but consumers' accessibility need to be strengthened.
\end{abstract}

Keywords: Benefit, consumer, consumption, market, preference, sea fish.

\section{Introduction}

Bangladesh is considered one of the most suitable regions for fisheries in the world, with the world's largest flooded wetland and the third largest aquatic biodiversity in Asia after China and India (Islam et al., 2017). Bangladesh, with its rich inland waters and river systems, has significant capture fishery and aquaculture potential. The twin verdicts of the International Tribunal for the Law of the Seas (ITLOS) in Hamburg, Germany, on the maritime boundary dispute between Bangladesh and Myanmar, on March 14, 2012, and the Permanent Court of Arbitration (PCA) on July 7, 2014 also on maritime dispute between India and Bangladesh 
have given Bangladesh an absolute sovereignty on a vast maritime area. On the overall, an 111,631 square kilometers was assigned to Bangladesh of the relevant area with Myanmar (approximately 171,832 square kilometers to Myanmar) and 19,467 square kilometers of 25,602 square kilometers with India.

The favourable geographic position of Bangladesh comes with a large number of aquatic species and provides plenty of resources to support fisheries potential. In the Bay of Bengal alone, a total of 490 species of fish belonging to 133 families were recorded of which 65 species are of commercial importance (Maruf, 2014). Unfortunately, most of these vast resources remain unexplored. If the country could utilize this area effectively, it will actually open up a scope to meet up with the demand of its vast population and expand export.

However, fish is the main source of animal protein in Bangladesh, it constitutes 63 percent of protein supply in the national diet (DoF, 2014). Fish is a high-protein, low-fat food that provides a range of health benefits. Whitefleshed fish, in particular, is lower in fat than any other source of animal protein, and oily fish are high in omega-3 fatty acids, or the "good" fats. Since the human body cannot make significant amounts of these essential nutrients, fish makes an important part of the diet. Besides, the fisheries sector plays a very important role in the national economy, contributing 3.69 percent to the Gross Domestic Product (GDP) of the country and 22.60 percent to the agricultural GDP (FRSS, 2016). Over the last 10 years (2004-2005 to 2013-2014 fiscal year), the fisheries growth was fairly steady at an average of 5.38 percent per year (FRSS, 2016).

Across Bangladesh, two types of fishes are mainly cultivated, viz. fresh water fish and sea water fish. But, most of Bangladeshi prefer fresh water fish to sea fish (Galib, 2011). Fish consumption depends on many factors such as increasing population along with sufficient supply of fish and fish products, demand, income, education level, consumer preference and fish prices (Feng et al., 2000). Monthly per capita consumption of different types of fish increases with the increase of monthly income (Leek et al., 2000). Freshness and taste are the most important factors for fish purchase in Bangladesh. By and large, there exist inadequate literature that specifically studied consumers' preference for sea fish consumption in Dhaka city. This was stressed by Ayubi and Ara (2017). It is therefore, high time the preferences and factors related to the consumption of sea fish are assessed. So, the present study attempts to examine consumers' preference for sea fish consumption in Dhaka city of Bangladesh.

\section{Methodology}

The study involved a cross sectional survey conducted during summer 2018 in four areas, namely; Uttara, Khilkhet, Mirpur, Jatrabari under Dhaka city. All the households around the four selected markets (Uttara, Khilkhet, Mirpur and Jatrabari) constituted the population of the study. For convenience, 30 households were selected from each of the four areas following quota sampling technique. Thus, a total of 120 households constituted the sample size of the study. Household heads that buy and consume sea fish were considered as the unit of analysis.

The data were collected using interview schedule. In addition, direct observation was made during the administration of interview schedule to the respondents. The preference for sea fish in the present study was measured on the basis of taste, odor, price and appearance as perceived by the respondents, and it was expressed in frequency and percent.

The SPSS (Statistical Package for Social Sciences) computer package was used to perform data analysis. Descriptive statistical measures like range, mean, frequency and percent distribution, standard deviation were used to describe and interpret the data. For exploring association between selected characteristics of the sea fish consumers and their consumption of 
sea fish chi-square test was used. Throughout the study 5.0 percent $(0.05)$ level of significance with an accompanying 95.0 percent confidence level were used as the basis for determining the association (chi-square) between the selected variables.

\section{Results and Discussion}

This section presents the results of the study and their logical interpretation accompanied by relevant discussions. It is thus as follows:

\subsection{Available sea fish in the market}

During visit to the four markets, twenty species of sea fish were observed. Among them Lates calcarifer, Pampus chinensis, Penaeus monodon, Tenualosa ilisha, Harpadon nehereus, Euthynnus affinis, Lepturacanthus savala, etc. were most prominent. These fishes were reported chilled, frozen or dried condition throughout the year. Maximum time, the sea fish were brought

Table 1. Available sea fish in Dhaka city market from Chattogram, Cox's Bazar, Khulna and Shatkhira regions of southern Bangladesh, which is predominantly coastal area.

According to the marketers' information, the available sea fish species in the selected markets are consumed in different ways such as dried, chilled or chilled and dried. The nature of fish condition in Bangladesh market is usually a function of consumers' demand and ingredients required to prepare a meal. On the other hand, traditional practice and need to preserve the fish for long time in order to maximise profit by the seller also determine the nature of the fish brought to the market.

\subsection{Consumption of sea fish}

Out of the 20 observed species of sea fish in the selected markets, 17 species are commonly consumed in the study areas as presented in Table 2.

\begin{tabular}{llll}
\hline SN & Local Name & Scientific Name & Condition \\
\hline 1 & Bhetki & Lates calcarifer & Chilled \\
2 & Rupchanda & Pampus chinensis & Chilled \\
3 & Bagda Chingri & Penaeus monodon & Chilled \\
4 & Loitta & Harpadon nehereus & Dried \\
5 & Ilish & Tenualosa ilisha & Dried and Chilled \\
6 & Churi & Lepturacanthus savala & Dried \\
7 & Rita & Rita rita & Chilled \\
8 & Poa & Pama pama & Dried \\
9 & Phasa & Sardina pilchardus & Dried \\
10 & Sardin & Polynemus indicum & Chilled \\
11 & Lakkha & Pampus argenteus & Dried \\
12 & Foli Chanda & Johnius argentatus & Dried \\
13 & Lal Poa & Odontamblyopus rubicundus & Dried \\
14 & Chewa & Decutor reconied \\
15 & Tak Chanda & Coilia dussumieri & Dried \\
16 & Olua & Coilia quadrifilis & Dried \\
17 & Megha Olua & Congresox talabonoides & Dried \\
18 & Kamila & Mugil cephalus & Dried \\
19 & Bhangon & Euthynnus affinis & Chilled and Dried \\
20 & Tuna & &
\end{tabular}


Table 2. Distribution of respondents according to taste

\begin{tabular}{lccc}
\hline \multicolumn{1}{c}{$\begin{array}{c}\text { Available fish in market } \\
\text { (Local name) }\end{array}$} & \multicolumn{3}{c}{ Sea fish consumption } \\
\cline { 2 - 4 } & Frequency & \% & Rank \\
\hline Ilish & 115 & 95.83 & $1^{\text {st }}$ \\
Rupchanda & 110 & 91.67 & $2^{\text {nd }}$ \\
Bagda Chingri & 90 & 75.00 & $3^{\text {rd }}$ \\
Bhetki & 89 & 74.17 & $4^{\text {th }}$ \\
Churi & 88 & 73.33 & $5^{\text {th }}$ \\
Tuna & 75 & 62.50 & $6^{\text {th }}$ \\
Loitta & 70 & 58.33 & $7^{\text {th }}$ \\
Foli Chanda & 65 & 54.16 & $8^{\text {th }}$ \\
Phasa & 56 & 46.67 & $9^{\text {th }}$ \\
Lal Poa & 45 & 37.50 & $10^{\text {th }}$ \\
Poa & 40 & 33.33 & $11^{\text {th }}$ \\
Sardin & 25 & 20.83 & $12^{\text {th }}$ \\
Rita. & 20 & 16.67 & $13^{\text {th }}$ \\
Chewa & 15 & 12.50 & $14^{\text {th }}$ \\
Olua & 13 & 10.83 & $15^{\text {th }}$ \\
Lakkha & 07 & 5.83 & $16^{\text {th }}$ \\
Bhangon & 06 & 5.00 & $17^{\text {th }}$ \\
\hline
\end{tabular}

Table 3. Distribution of respondents according to their sea fish consumption

\begin{tabular}{lccccc}
\hline Category & $\begin{array}{c}\text { Amount consumed } \\
\text { (kg/month) }\end{array}$ & Frequency & Percent & Mean & SD \\
\hline Low consumption & Up to 4.5 & 62 & 51.67 & & \\
Medium consumption & $4.6-6.5$ & 47 & 39.2 & 5.49 & 1.54 \\
High consumption & $>6.5$ & 11 & 9.17 & & \\
\hline
\end{tabular}

Among the 17 species, more than 50.0 percent of the respondents consumed Ilish $(95.83 \%)$, Rupchanda (91.67\%), Bagda chingri (75.0\%), Bhetki (74.17\%), Churi (73.33\%), Tuna (62.5\%), Loitta $(58.33 \%)$, and Foli chanda $(54.16 \%)$ due to their taste, thus, ranked accordingly in the order of respondents' preference. However, a considerable portion of the respondents also consumed Phasa (46.67\%), Foli Chanda $(54.16 \%)$, Lal poa $(37.5 \%)$, Poa $(33.33 \%)$, and Sardin $(20.83 \%)$. The degree of preference for the sea fishes implies the consumers' need based on what market offers that is presumed to be suitable by the consumers. Also, it was observed that the preference could differ based on availability and what or who the meal is to be prepared for. Bangladesh is blessed with vast resources in sea waters, as exemplified by the findings in Table 1 and 2. However, despite the abundance of sea resources, only about 15.41 percent of Bangladesh's total fish production is contributed by the marine sector (DoF, 2017), which compelled the present government to set utmost priority on protection, conservation and biodiversity of marine and coastal resources.

Information presented in the Table 3 illustrates the categories of respondents based on their household sea fish consumption level in $\mathrm{kg} / \mathrm{month}$. 
Respondents' average household ( $\leq 12$ members) monthly consumption of sea fish was $5.49 \mathrm{~kg}$, which indicates the commonly consumed amount of sea fish in the study area. The opportunity to choose among alternatives and average monthly consumption of $5.49 \mathrm{~kg} /$ respondent's household were also a clear sign of homogeneity of the respondents regarding their sea fish consumption. Although, the low consumption category is $\leq 4.5 \mathrm{~kg} /$ month, it is quite appreciative compared to 2.98 $\mathrm{kg} /$ person/year reported by Can et al. (2015) in Antakya city of Turkey. Hanson et al. (2012) in a similar study indicated that the amount of sea fish consumed increases with increase in income. The quantity of sea fish consumed varies across individuals based on their needs and ability.

\subsection{Factors associated with sea fish consumption}

There are several factors associated with the consumers' household consumption of sea fish. In the present study, association between respondents selected characteristics (age, gender, education level, income and religious view) and their household consumption of sea fish was determined using chi-square test and presented as follows:

Findings presented in Table 4 imply that among the 120 respondents; 25 were young in which 68.0 percent consumed sea fish, 51 were middle age among which 78.4 percent consumed sea fish and 44 were old from whom 68.2 percent consumed sea fish.

Table 4. Association of sea fish consumption with age

\begin{tabular}{lcccc}
\hline \multirow{2}{*}{ Categories } & \multirow{2}{*}{$\begin{array}{c}\text { Respondents } \\
(\mathbf{N = 1 2 0})\end{array}$} & $\begin{array}{c}\text { Crequency } \\
\text { (Yes) }\end{array}$ & $\begin{array}{c}\text { Frequency } \\
\text { (No) }\end{array}$ & Chi Square \\
\cline { 3 - 4 } & 25 & $17(68.0 \%)$ & $8(32.0 \%)$ & $3.240^{\text {ns }}$ \\
Young (up to 35) & 51 & $40(78.4 \%)$ & $11(21.6 \%)$ & $16.490^{* *}$ \\
Middle (36 - 60) & 44 & $30(68.2 \%)$ & $14(31.8 \%)$ & $5.818^{*}$ \\
\hline
\end{tabular}

$\mathrm{NS}=$ no significant, $*=5 \%$ level of significant, $* *=1 \%$ level of significant

Table 5. Association of sea fish consumption with gender

\begin{tabular}{lcccc}
\hline \multicolumn{1}{c}{ Gender } & $\begin{array}{c}\text { Respondents } \\
(\mathbf{N}=\mathbf{1 2 0})\end{array}$ & \multicolumn{2}{c}{ Consumption } & Chi Square \\
\cline { 3 - 4 } & & $\begin{array}{c}\text { Frequency } \\
\text { (Yes) }\end{array}$ & $\begin{array}{c}\text { Frequency } \\
(\mathbf{N o})\end{array}$ & \\
\hline Men & 61 & $51(83.6 \%)$ & $10(16.4 \%)$ & $27.557^{* *}$ \\
Women & 59 & $40(67.8 \%)$ & $19(32.2 \%)$ & $7.475^{* *}$ \\
\hline
\end{tabular}

$*=5 \%$ level of significant, $* *=1 \%$ level of significant

Table 6. Association of sea fish consumption with education level

\begin{tabular}{lcccc}
\hline \multirow{2}{*}{ Education level } & \multirow{2}{*}{$\begin{array}{c}\text { Respondents } \\
(\mathbf{N = 1 2 0})\end{array}$} & \multicolumn{2}{c}{ Consumption } & \multirow{2}{*}{ Chi Square } \\
\cline { 3 - 4 } & 19 & $10(52.6 \%)$ & $9(47.4 \%)$ & $0.053^{\mathrm{n}}$ \\
\hline S.S.C & 35 & $30(85.7 \%)$ & $5(14.3 \%)$ & $17.857^{* *}$ \\
H.S.C & 66 & $62(93.4 \%)$ & $4(6.6 \%)$ & $50.970^{* *}$ \\
University & & \multicolumn{2}{c}{ Frequency (Yes) } & Frequency (No) \\
\hline
\end{tabular}

$\mathrm{NS}=$ no significant, $* *=1 \%$ level of significant 
Positively significant chi-square values in case of middle and old age respondents indicate that, there is a positive association between age and sea fish consumption. It might be that this age categories (36 - 60) had vast knowledge on beneficial effects of sea fish consumption more than those of less age who were mostly inclined towards junk foods.

Findings presented in Table 5 indicate that among the respondents; 61 were male, 59 were female. Of the male respondents, 83.6 percent preferred sea fish while in case of the female respondents, 67.8 percent preferred the sea fish. Positively significant chi-square values in case of both men and women respondents indicate that, there is a significant association between gender and sea fish consumption. But, the percent consumption is higher in men than women.

Results shown in the Table 6 indicate that, out of the respondents; 19, 35 and 66 studied up to S.S.C, H.S.C and university levels. Among them, 52.6 percent, 85.7 percent 93.4 percent, respectively, consumed sea fish. Highest chisquare value in case of the respondents who studied up to university level indicates that, there is a positive association between education level and sea fish consumption. Results also indicate that the percent consumption is higher in highly educated respondents more than the less educated.

Findings furnished in Table 7 reveal that 93.3 percent of the respondents of medium income category and 68.0 percent of the high income category preferred sea fish more than those that fall under low income category. The 93.3 percent of the respondents in the medium income category with highest chi-square value indicates that, there is a positive association between income level and sea fish consumption. But, both the high and low income categories were not found significantly related with the consumption of sea fish.

Results in Table 8 reveal that among the respondents 84 were Muslims and 36 practice Hinduism. Out of the said number, 90.5 and 83.3 percent of Muslim and Hindus, respectively, consumed sea fish. Though in both the religions there found association with consumption of seas fish, higher chi-square value was found for Islam. This might happen because of the predominance of Muslims in Dhaka city.

Table 7. Association of sea fish consumption with income

\begin{tabular}{lcccc}
\hline Income (BDT) & $\begin{array}{c}\text { Respondents } \\
(\mathbf{N = 1 2 0})\end{array}$ & \multicolumn{2}{c}{ Consumption } & Chi \\
\cline { 3 - 4 } & & $\begin{array}{c}\text { Frequency } \\
\text { Sqes) }\end{array}$ & $\begin{array}{c}\text { Frequency } \\
(\mathbf{N o})\end{array}$ & \\
\hline Low income $(<240,000)$ & 23 & $10(43.48 \%)$ & $13(56.52 \%)$ & $0.391^{\mathrm{ns}}$ \\
Medium income $(240,000$ & 75 & $70(93.3 \%)$ & $5(6.3 \%)$ & $56.333^{* *}$ \\
$\begin{array}{l}720,000) \\
\text { High income }(>720,000)\end{array}$ & 22 & $15(68.0 \%)$ & $7(32.0 \%)$ & $2.909^{\mathrm{ns}}$ \\
\hline
\end{tabular}

$\mathrm{NS}=$ no significant, $* *=1 \%$ level of significant

Table 8. Association of sea fish consumption with religious view

\begin{tabular}{lcccc}
\hline \multirow{2}{*}{ Religious view } & \multirow{2}{*}{$\begin{array}{c}\text { Respondents } \\
(\mathbf{N = 1 2 0})\end{array}$} & Frequency (Yes) & Frequency (No) & $\begin{array}{c}\text { Chi } \\
\text { Square }\end{array}$ \\
\cline { 3 - 4 } Muslim & 84 & $76(90.5 \%)$ & $8(9.5 \%)$ & $55.048^{* * *}$ \\
Hinduism & 36 & $30(83.3 \%)$ & $6(16.7 \%)$ & $16.000^{* *}$ \\
\hline
\end{tabular}

$* *=1 \%$ level of significant 
In this study, age, gender, educational level, income and religious view have shown a significantly positive association with sea fish consumption in Dhaka city. As for the age, it is from 30s upward. In this regard, an investigation conducted by Verbeke and Vackier (2005) on the determinants of fish consumption behaviour in Belgium using Theory of Planned Behaviour found that fish consumption increases with age. Possibly, due to increased knowledge and awareness, and the need to maintain a healthy lifestyle. As such, a study in USA by Brouwer and Mosack (2015) obtained that consumers characterized by a healthy lifestyle are more likely to have healthy diets that are composed of fish. On the contrary, Kaimakoudi et al. (2013) obtained that high-potential fish consumers are young.

Gender-wise, regardless of its positively significant association with the consumption of sea fish, men consumed more fish than women. This could happen because, men are mainly involved in buying, but women are involved in both buying and preparing the fish for consumption. The women therefore know the difficulties in processing fish-which they mostly handle-for consumption, especially when the household is composed of a quite number of members. But, differing from the present findings, Sechena et al. (2003) claimed that women consumed slightly more seafood after adjusting for body weight, and Verbeke and Vackier (2005) reported that in Belgium women were found to consume more fish than men.

In terms of education, high school and university graduates educational levels expressed significantly positive association with sea fish consumption. Perhaps, because educated people are more careful about their health issues than the less educated people. A number of recent studies (Supartini et al., 2018; Can et al., 2015; Kaimakoudi et al., 2013) have indicated association between education and fish consumption. On the other hand, a United States study by Burger et al. (1999) shown, however, that there is an opposite association between fish consumption and education where people who did not graduate from high school ate fish more often than those who graduated from high school. Çolakoğlu et al. (2006) also disclosed that there is no association between educational level and fish consumption in Canakkale City of Turkey, while Verbeke and Vackier (2005) found that there is no meaningful relationship between education and fish consumption frequency in Belgium. However, the present findings corroborate the recent revelations by Supartini et al. (2018); Can et al. (2015) and Kaimakoudi et al. (2013).

Interestingly, both low and high income categories happened to have no significant association with sea fish consumption. As for the low income earners, it might be as a result of financial constraint which limits budget and impose prioritization on the individual who would have to forego some choices, while the high income earners do have alternatives and ability to opt for any choice of interest. Kreider et al. (1993) asserted that consumers believe that seafood is more expensive than poultry, beef, etc., and if the price is too much higher than that of other muscle foods, they decrease their seafood purchases. However, Trondsen et al. (2004) and Can et al. (2015) stated that higher fish consumption is associated with a higher level of income.

With regards to religion, a study conducted by Madhavi and Kusuma (2015) in Nellore and Tirupati cities of India exposed both significant and no significant association, respectively, between religion and fish consumption. Anyways, both Islam and Hinduism do not forbid the consumption of fish.

\subsection{Consumers' preference for sea fish consumption}

Preference here refers to the subjective tastes of an individual. Consumers' degree of subjective taste largely depends upon the age, gender, income, education level and religious view. Consumers' preference also depends on various factors such as taste, odor, price and appearance. 
Moreover, taste, quality and price of the fish also act as the mediator of the consumers' preferences for fish consumption.

According to taste, majority of the respondents preferred Ilish (95.0\%), Rupchanda (94.34\%), Bagda chingri (91.45\%), Loitta $(89.25 \%)$, Churi $(85.0 \%)$ and Tuna $(81.82 \%)$. Some fish such as Poa $(67.45 \%)$ and Phasa $(68.76 \%)$ are preferred due to their low price which made them affordable even on low budget. When it comes to consumer preference for sea fish, a number of factors come into play, these include bones, smell, and taste (Pieniak et al., 2008), appearance (colour, shape, homogeneity, defects), smell, taste, texture or consistency (Myrland et al., 2000; Leek et al., 2000). In particular, purchase of sea fish for consumption by households has been reported to be influenced by attributes that include sensory properties (Kinnucan et al., 1993) and price/value for money (Sayin et al., 2010), which support the findings of this study. Similarly, opinion on benefits of sea fish could play a vital role in determining preference. So, consumers' opinion on benefits of sea fish consumption could be swayed by a numbers of motives which usually stem from awareness, environment, belief and purchasing power.

3.5 Opinion on benefits of sea fish consumption Fish is a high-protein, low-fat food that provides a range of health benefits. Since the human body cannot make significant amount of essential nutrients, fish makes an important part of the diet for nutrition. Out of 7 benefits identified, 91.0 percent of the respondents agreed that sea fish is 'beneficial to heart', 82.0 percent agreed that it 'keep the eyes bright' and 69.0 percent agreed that sea fish is 'enriched with essential nutrients,' ranked $1 \mathrm{st}$, 2nd and $3^{\text {rd }}$, respectively. On the other end, the respondents opined that sea fish 'help to prevent depression' ranked $7^{\text {th }}$. Some empirical evidence affirmed nutritional value (Kleppe, Iversen \& Stensaker, 2002), health related benefits (Leek, Maddock \& Foxall, 2000) and perceived benefits (Burger \& Gochfeld, 2009) as motives behind seafood consumption. Basically, consumption of oily fish such as sea fish reduces the risk heart complication (Whelton et al., 2004; FAO/WHO, 2011), may be protective against certain cancers (Norat et al., 2005; Geelen et al., 2007), death/sudden death (Nakamura et al., 2005) etc.

Table 9. Distribution of respondents according to their preferences of sea fish

\begin{tabular}{|c|c|c|c|c|c|}
\hline \multirow{2}{*}{$\begin{array}{l}\text { Available fish } \\
\text { (Local name) }\end{array}$} & \multirow{2}{*}{ Frequency } & \multicolumn{4}{|c|}{ Preference Criteria (\% respondents) } \\
\hline & & Taste & Odor & Price & Appearance \\
\hline Bhetki & 77 & 81.82 & 3.70 & 0.00 & 14.48 \\
\hline Rupchanda & 90 & 94.34 & 5.66 & 0.00 & 0.00 \\
\hline Bagda Chingri & 97 & 91.45 & 8.55 & 0.00 & 0.00 \\
\hline Loitta & 81 & 89.25 & 4.67 & 6.08 & 0.00 \\
\hline Ilish & 101 & 95.00 & 1.70 & 0.00 & 3.30 \\
\hline Churi & 59 & 85.00 & 13.80 & 0.00 & 1.20 \\
\hline Tuna & 67 & 81.82 & 3.70 & 0.00 & 14.48 \\
\hline Rita & 29 & 59.88 & 0.00 & 33.80 & 6.32 \\
\hline Poa & 25 & 19.64 & 3.55 & 67.45 & 9.36 \\
\hline Phasa & 35 & 25.40 & 5.30 & 68.76 & 0.54 \\
\hline Sardin & 39 & 24.33 & 22.80 & 29.42 & 23.45 \\
\hline Lakkha & 17 & 23.52 & 29.41 & 29.41 & 17.64 \\
\hline Foli Chanda & 20 & 23.89 & 24.33 & 24.67 & 27.11 \\
\hline Lal Poa & 07 & 25.50 & 23.90 & 26.10 & 24.50 \\
\hline Chewa & 06 & 24.00 & 26.20 & 25.00 & 22.80 \\
\hline Olua & 08 & 25.50 & 23.90 & 26.10 & 24.50 \\
\hline Bhangon & 06 & 23.89 & 24.33 & 24.67 & 27.11 \\
\hline
\end{tabular}


Table 10. Rank order of the benefits of sea fish consumption

\begin{tabular}{|c|c|c|c|c|c|}
\hline \multirow{2}{*}{$\begin{array}{l}\text { Benefits of sea fish } \\
\text { consumption }\end{array}$} & \multicolumn{3}{|c|}{ Response (\% respondents) } & \multirow{2}{*}{$\begin{array}{c}\text { Benefit } \\
\text { Index (BI) }\end{array}$} & \multirow[t]{2}{*}{ Rank } \\
\hline & Agree & Neutral & Disagree & & \\
\hline Beneficial to heart & $\begin{array}{c}109 \\
(91.0)\end{array}$ & $\begin{array}{c}3 \\
(2.0)\end{array}$ & $\begin{array}{c}8 \\
(7.0)\end{array}$ & 341 & $1^{\mathrm{st}}$ \\
\hline $\begin{array}{l}\text { Keep the eyes bright and } \\
\text { healthy }\end{array}$ & $\begin{array}{c}98 \\
(82.0)\end{array}$ & $\begin{array}{c}4 \\
(3.0)\end{array}$ & $\begin{array}{c}18 \\
(15.0)\end{array}$ & 320 & $2^{\text {nd }}$ \\
\hline $\begin{array}{l}\text { Enriched with essential } \\
\text { nutrients }\end{array}$ & $\begin{array}{c}83 \\
(69.0)\end{array}$ & $\begin{array}{c}13 \\
(11.0)\end{array}$ & $\begin{array}{c}24 \\
(21.0)\end{array}$ & 299 & $3^{\text {rd }}$ \\
\hline $\begin{array}{l}\text { Improve health condition of the } \\
\text { body }\end{array}$ & $\begin{array}{c}82 \\
(68.0)\end{array}$ & $\begin{array}{c}8 \\
(7.0)\end{array}$ & $\begin{array}{c}31 \\
(26.0)\end{array}$ & 293 & $4^{\text {th }}$ \\
\hline Protect inflammatory disease & $\begin{array}{c}80 \\
(67.0)\end{array}$ & $\begin{array}{c}8 \\
(7.0)\end{array}$ & $\begin{array}{c}32 \\
(25.0)\end{array}$ & 288 & $5^{\text {th }}$ \\
\hline $\begin{array}{l}\text { Protect the skin from ultra } \\
\text { violet damage }\end{array}$ & $\begin{array}{c}76 \\
(63.0)\end{array}$ & $\begin{array}{c}11 \\
(9.0)\end{array}$ & $\begin{array}{c}33 \\
(28.0)\end{array}$ & 283 & $6^{\text {th }}$ \\
\hline Help to prevent depression & $\begin{array}{c}42 \\
(35.0)\end{array}$ & $\begin{array}{c}58 \\
(48.0)\end{array}$ & $\begin{array}{c}20 \\
(17.0)\end{array}$ & 262 & $7^{\text {th }}$ \\
\hline
\end{tabular}

\section{Conclusions}

Sea fish is a reliable protein source and an essential provider of many nutrients that keep body function running and helps protects against some diseases, including cancer. Having adopted cross sectional survey design, the present study found that the respondents in Dhaka city approximately consumed 17 species of sea fish out of the 20 usually brought to the selected markets in the study area. The preferred sea fishes were consumed mainly for taste and in some cases for low price. Average monthly household sea fish consumption found was 5.49 $\mathrm{kg}$. Age, level of education, gender, annual income and religious view of the respondents showed significant positive association with their household sea fish consumption. The major benefits of sea fish consumption were identified as 'beneficial for heart', 'keeps the eyes bright', and 'enriched with essential nutrients.' However, irregular supply of sea fish and higher price were indicated as the major constraints to sea fish consumption. Since the results indicated that sea fish consumption and preference is not only specific to certain class of people (varies though), but limited by irregular supplies and higher prices, it is imperative to make necessary efforts by the Department of Fisheries and other responsible organisations (governmental and non-governmental) for increasing its consumption. These could come in the way of effective transportation and marketing systems for sea fish from the coastal area to other parts of the country so that it could be regularly available to the consumers at market places.

\section{References}

Akter S., 2014. Empowerment of rural women through agricultural technology intervention. Master Thesis, Bangabandhu Sheikh Mujibur Rahman Agricultural University, Gazipur-1706, Bangladesh.

Ayubi MM., Ara I. 2017. Fish consumption and socio-economic status of the rural people: a case study on Islamnagar village, Savar, Dhaka. Jahangirnagar University Journal of Biological Sciences, 6(2):39-46.

Brouwer AM., Mosack KE. 2015. Expanding the theory of planned behavior to predict healthy eating behaviors: Exploring a healthy eater identity. Nutrition and Food Science, 45: 39-53.

Burger J., Gochfeld M., Jeitner C., Burke S., Stamm T. 2007. Metal levels in Flathead Sole (Hippoglossoides elassodon) and 
Great Sculpin (Myoxocephalus polyacanthocephalus) from Adak Island, Alaska: Potential risk to predators and fishermen. Environmental Research, 103:62-69.

Burger J., Stephens WL., Jr. Boring CS., Kuklinski M., Gibbons JW., Gochfeld M. 1999. Factors in exposure assessment: Ethnic and socioeconomic differences in fishing and consumption of fish caught along the Savannah River. Risk Analysis, 19(3):427-438.

http://dx.doi.org/10.1111/j.1539-

6924.1999.tb00418.x

Can MF., Günlü A., Can HY. 2015. Fish consumption preferences and factors influencing it. Food Science \& Technology Campinas, 35(2): 339-346.

Çolakoğlu FA., İşmen A., Özen Ö, Çakır F., Yığın Ç., Drmanci HB. 2006. The evaluation of fish consumption in Çanakkale. EU Journal of Fisheries and Aquatic Science, 23(3): 387-392

DoF. 2014. National fish week compendium (In Bengali). Dhaka: Department of Fisheries, Ministry of Fisheries and Livestock, Government of Bangladesh.

DoF. 2017. Yearbook of Fisheries Statistics of Bangladesh 2016-17. Dhaka: Department of Fisheries. Ministry of Fisheries and Livestock, Government of Bangladesh.

FAO/WHO. 2011. Report of the joint FAO/WHO expert consultation on the risks and benefits of fish consumption. Rome, Geneva: Food and Agriculture Organization of the United Nations, World Health Organization.

Feng W., Winther U., Ziegler F. 2000. Consumer attitudes towards more sustainable food choices. Appetite, 62: 7-16.

FRSS. 2016. Fisheries resources survey system (FRSS), fisheries statistical report of Bangladesh 32, 1-52. Bangladesh: Department of Fisheries.
Galib SM. 2011. Puffer fishes: a common and an old threat in Bangladesh (online). http://en.bdfish.org/2011/01/puffer-fishthreat-bangladesh/

Geelen A., Schouten JM., Kamphuis C., Stam BE., Burema J., Renkema JMS., Bakker EJ., van't-Veer, P., Kampman E. 2007. Fish consumption, n-3 fatty acids, and colorectal cancer: A meta-analysis of prospective cohort studies. American Journal of Epidemiology, 166:1116-1125.

Haider M. 2010. Integrated pest management club for forecasting farmer's empowerment in rice production. Ph.D. Dissertation, Bangabandhu Sheikh Mujibur Rahman Agricultural University, Gazipur-1706, Bangladesh.

Hanson GD., Rauniyar GP., Dunn JM. 2012. Seafood preference in grocery stores and store characteristics. Presented at the World Aquaculture Society Annual Meeting, San Diego, CA, USA.

Islam MM., Shamsuzzaman MM., Mozumder H., Xiangmin X., Ming Y. 2017. Exploitation and conservation of coastal and marine fisheries in Bangladesh: Do the fishery laws matter? Marine Policy, 76:143-151.

Kaimakoudi E., Polymeros K., Schinaraki MG., Batzios C. 2013. Consumers' attitudes towards fisheries products. Procedia Technology, 8:90-96.

Kinnucan HW., Nelson RG., Hiariey J. 1993. US Preferences for fish and seafood: And evoked set analysis. Marine Resource Economics, 8: 222-225.

Kleppe IA., Iversen NM., Stensaker IG. 2002. Country images in marketing strategies: Conceptual issues and an empirical Asian illustration. Journal Brand Management, 10(1): 67-74.

Kreider CR., Gempesaw CM., Bacon JR., Toensmeyer UC., Groff AJ. 1993. An analysis of consumer perceptions of fresh fish and seafood in the Delmarva region. 
Journal of Food Distribution Research, 4:37-48.

Leek S., Maddock S., Foxall G. 2000. Situational determinants of consumption. British Food Journal, 102(1):18-39.

Madhavi D., Kusuma DL. 2015. Fish consumption pattern and its association with household characteristics in selected coastal and non-coastal districts of Andhra Pradesh. International Journal of Scientific Research, 4(5): 2472- 2478.

Maruf H. 2014. Fishery Resources of the upper Bay of Bengal. Indian Ocean Programme, Indian Ocean Fisheries Commission, Rome, FAO, IOFC/DEV/73/28. p. 28.

Myrland O., Trondsen T., Johnson RS., Lund E. 2000. Determinants of seafood consumption in Norway: Lifestyle, revealed preferences and barriers to consumption. Food Quality and Preference, 11:169-188.

Nakamura Y., Ueshima H., Okamura T., Kadowaki T., Hayakawa T., Kita Y., Tamaki S., Okayama A. 2005. Association between fish consumption and all-cause and cause-specific mortality in Japan: NIPPON DATA80, 1980-99. American Journal of Medicine, 118:239245.

Norat T., Bingham S., Ferrari P., Slimani N., Jenab M., Mazuir M., Overvad K., Olsen A., Tjonneland A., Clavel F., BoutronRuault MC., Kesse E., Boeing H., Bergmann MM., Nieters A., Linseisen J., Trichopoulou A., Trichopoulos D., Tountas Y., Berrino F., Palli D., Panico S., Tumino R., Vineis P., Bueno-DeMesquita HB., Peeters PHM., Engeset D., Lund E., Skeie G., Ardanaz E. 2005. Meat, fish, and colorectal cancer risk: The European prospective investigation into cancer and nutrition. Journal National Cancer Institute, 97:906-916.

Pieniak Z., Verbeke W., Perez-Cueto F., Bruns $\varnothing$ K., De Henauw S. 2008. Fish consumption and its motives in households with versus without self- reported medical history of CVD: a consumer survey from five European countries. BMC Public Health, 8(1):306. http://dx.doi.org/10.1186/1471-2458-8306

Rahman MZ., Kashem MA., Rahman MH., Haq ABMA. 2008. People's participation in coastal biodiversity management activities in St. Martins Island. Bangladesh Journal of Extension Education, 20(1\&2):113116.

Sayin C., Emre Y., Mencet MN., Karaman S., Tascioglu Y. 2010. Analysis of factors affecting fish purchasing decisions of the household: Antalya district case. Journal Animal Veterinary Advances, 9(12):16891695.

Sechena R., Liao S., Lorenzana R., Nakano C., Polissar N., Fenske R. 2003. Asian American and Pacific Islander seafood consumption: A community-based study in King County, Washington. Journal of Exposure Analysis and Environmental Epidemiology, 13(4): 256-266. http://dx.doi.org/10.1038/sj.jea.7500274

Supartini A., Oishi T., Yagi N. 2018. Changes in fish consumption desire and its factors: A comparison between the United Kingdom and Singapore. Foods, 7(7):97

Trondsen T., Braaten T., Lund E., Eggen AE. 2004. Eggen health and seafood consumption patterns among women aged 45-69 years: A Norwegian seafood consumption study. Food Quality and Preference, 15: 117-128. http://doi:10.1016/S0950-3293(03)000387

Verbeke W., Vackier I. 2005. Individual determinants of fish consumption: Application of the theory of planned behavior. Appetite, 44: 67-82.

Whelton SP., He J., Whelton PK., Muntner P. 2004. Meta-analysis of observational studies on fish intake and coronary heart disease. American Journal of Cardiology, 93(9): 1119-1123. 